\title{
ARE SHADE TOLERANCE, SURVIVAL, AND GROWTH LINKED? LOW LIGHT AND NITROGEN EFFECTS ON HARDWOOD SEEDLINGS ${ }^{1}$
}

\author{
Michael B. WALters \\ Department of Natural Resources and Environmental Studies, University of Northern British Columbia, \\ Prince George, British Columbia, Canada V2N $4 Z 9$ \\ PETER B. REICH \\ Department of Forest Resources, University of Minnesota, St. Paul, Minnesota 55108 USA
}

\begin{abstract}
Variation in shade tolerance is a primary mechanism driving succession in northern deciduous forests. However, little is known about interspecific differences in the traits responsible for shade tolerance. Is shade tolerance due to the ability to grow or survive in deep shade, or both? How do plant morphology and photosynthesis relate to growth in shade? Is low light the sole critical stress determining differences in "shade tolerance" or do belowground resources interact with low light to affect growth and survival? In this study we address these questions for seedlings of Betula papyrifera Marsh., Betula alleghaniensis Britton, Ostrya virginiana (Mill.) K. Koch, Acer saccharum Marsh., and Quercus rubra L. grown for $2 \mathrm{yr}$ in outdoor shade houses in a complete factorial of low light ( 2 and $8 \%$ open sky) and nitrogen (forest soil and forest soil plus $200 \mathrm{~kg} \mathrm{~N} \cdot \mathrm{ha}^{-1} \cdot \mathrm{yr}^{-1}$ ). For these seedlings we examined effects of light and nitrogen on the interrelationships among survival, growth, and shade tolerance and explored the physiological bases of shade tolerance by examining the relationship of plant morphology and photosynthesis to growth.

Nitrogen amendments did not have a significant effect on any plant trait at either light level. In $8 \%$ light, growth and survival were highest for shade-intolerant Betula papyrifera and mid-tolerant Betula alleghaniensis, lower for shade-tolerant Ostrya and Acer, and lowest for disturbance-adapted Quercus. In 2\% light, species rankings reversed as Ostrya and Acer had higher growth and survival than the other species. Second-year survival was strongly related to 1 st-yr growth $(P<0.001)$, whereas relationships with 1 st-yr plant mass and 1 st$\mathrm{yr}$ absolute growth rates were weak. Therefore, survival of shade-tolerant species at $2 \%$ light was related to their maintenance of positive growth, whereas intolerant species had growth near zero and high rates of mortality. In both 2 and $8 \%$ light photosynthetic rates on mass (but not area) bases and the proportion of the plant in leaves (leaf area ratio and leaf mass ratio) were positively related to growth. Greater rates of growth and survival for shade-tolerant species in very low light, and for intolerant species in higher light, suggest that there is a species-based trade-off between maximizing growth in high light and minimizing the light compensation point for growth. This trade-off may be an important mechanism driving forest community dynamics in northern hardwood forests.
\end{abstract}

Key words: Acer saccharum; allocation; Betula alleghaniensis; Betula papyrifera; forest succession; growth rate; nitrogen; Ostrya virginiana; photosynthesis; Quercus rubra; shade tolerance; survival.

\section{INTRODUCTION}

Variation in "shade tolerance" is a key factor underlying forest successional dynamics. Shade-intolerant seedlings of species dominating early successional seres tend to be restricted to open, "high-light" habitats where they grow rapidly. Conversely, seedlings of "shade-tolerant" species dominating late successional seres are abundant beneath closed forest overstories where they are presumed to be able to "out grow" and/ or "out survive" less tolerant species (Spurr and Barnes 1980). Shade-tolerance classifications for tree species have been developed for many regions, but generally these are based on subjective observation and/

\footnotetext{
${ }^{1}$ Manuscript received 12 December 1994; revised 23 May 1995; accepted 24 May 1995; final version received 20 July 1995.
}

or assessment of characters thought to be related to growth in low light (Zon and Graves 1911, Baker 1949). Few studies have directly tested the possibility that both seedling growth and survival in forest understories fit these classifications (but for trees see Lorimer 1981 and for saplings see Pacala et al. 1993, Kobe et al. 1995). Several studies have examined growth (but not survival) in low light and most of them report reduced growth rates for all species in low light. However, most of these studies report higher low-light growth rates for shade-intolerant than tolerant species (Loach 1970, McClendon and McMillen 1982, Ramos and Grace 1990, Chazdon 1992, Kitajima 1994), while fewer report the opposite (Pompa and Bongers 1988, Denslow et al. 1990). Previous studies on five species of northern hardwoods that vary widely in shade tolerance are consistent with the former result (Walters et 
al. $1993 a, b)$. In controlled-environment rooms we grew Betula papyrifera, Betula alleghaniensis, Ostrya virginiana, Acer saccharum, and Quercus rubra in moderately high light $\left(14 \mathrm{~h}\right.$ at $610 \mu \mathrm{mol} \cdot \mathrm{m}^{-2} \cdot \mathrm{s}^{-1}$, photosynthetic photon flux density (PPFD), $\approx 75-100 \%$ clear-sky total daily flux) and the two Betula and Ostrya in moderately low light $\left(14 \mathrm{~h}\right.$ at $125 \mu \mathrm{mol} \cdot \mathrm{m}^{-2} \cdot \mathrm{s}^{-1}$ PPFD, $\approx 15-20 \%$ clear-sky daily flux). We found that shade-intolerant $B$. papyrifera had higher growth rates than the other species in both high and moderately low light. Prima facie, the bulk of these results suggests that maximizing potential low-light growth rates is not an important and general component of shade tolerance. However, there are several potential reasons why higher growth rates for shade-intolerant than tolerant species have often been observed in low light studies: (1) growth rate potential in low light may be generally higher for shade-tolerant than intolerant species but only at very low light levels; (2) belowground resources (e.g., nitrogen, water) can colimit growth (Korstian and Coile 1938, Shirley 1945) and the degree of colimitation may vary with shade tolerance; (3) allocation to defense and storage in low-light plants may occur at a trade-off to growth (e.g., Chapin et al. 1990); and (4) variation in traits with no direct connection to growth potential or biomass conservation (e.g., seed dispersal and seedling establishment) in low light may be responsible for apparent differences in "shade tolerance."

In this report we explore some of these possibilities for the same five species we studied previously (Walters et al. $1993 a, b$ ). In outdoor shade houses over 2 yr we examined growth, survival, and their interrelationships at low and very low light levels ( 2 and $8 \%$ of full light) and at two levels of nitrogen availability (forest soil and forest soil plus nitrogen). We also explored hypothetical physiological bases of shade tolerance by comparing morphological and photosynthetic characteristics among species and examining their relationships with growth rate. High photosynthetic efficiency in low light and allocation to a large leaf area are assumed to be components of shade tolerance (Spurr and Barnes 1980), yet multiple-species tests of these assumptions in low light are rare (Loach 1967, 1970). In our previous work (Walters et al. 1993b) we found that growth rate in high light was correlated with in situ photosynthetic rate and allocation to leaves, whereas in moderately low light growth rate was correlated only with allocation to leaves. Thus leaf allocation could be more important than leaf photosynthetic rate as a source of variation in low light growth rates.

In this study, five questions were addressed: (1) Do growth rankings reverse from those reported for high light levels (Walters et al. 1993a) such that shade-tolerant species have the highest growth rates at low and very low light levels? (2) Does variation in nitrogen availability change species growth rankings in low light? (3) Is survival in low light related to reported shade tolerances? (4) Is survival related to growth? and (5) In very low light is growth rate related to in situ photosynthetic rates and/or to allocation to leaves?

\section{Materials AND METHODS}

\section{Species and pretreatment}

We studied five co-occurring species with a wide range of reported shade tolerances. Three of the species (Betula papyrifera, Betula alleghaniensis, and Ostrya virginiana) are Betulaceae family members. Ostrya and Acer saccharum seedlings are common in forest understories and considered shade tolerant (Baker 1949, Braun 1950, Curtis 1959). Betula alleghaniensis commonly regenerates in tree-fall gaps and is tolerant of moderate shade (Curtis 1959, Forcier 1975). Quercus rubra is considered tolerant of moderate shade, but it seems to do best in sites disturbed by fire (Crow 1988, Kruger 1992). B. papyrifera is considered shade intolerant since it is rarely found in forest understories and because its seedlings colonize areas opened by large disturbance (Baker 1949, Braun 1950, Curtis 1959).

Quercus seeds from the Hiawatha National Forest, Michigan $\left(\approx 46^{\circ} \mathrm{N}, 87^{\circ} \mathrm{W}\right)$, were obtained from Toumey Nursery (USDA, Watersmeet, Michigan, USA). Seeds of the other species were collected from several parent trees in Vilas County, Wisconsin $\left(\approx 46^{\circ} \mathrm{N}, 89^{\circ}\right.$ $\mathrm{W}$ ), in autumn and early winter 1989. Seedlings were germinated in late April 1990 and were grown individually in $0.15-\mathrm{L}$ paper cups in washed silica sand. They were watered daily and fertilized with a halfstrength Hoagland's nutrient solution twice weekly. Seedlings were grown in a glass house (University of Wisconsin-Madison) inside of shade frames covered with one layer of $50 \%$-transmittance neutral-density shade cloth, where plants received $\approx 20 \%$ of open-sky light. After an average of $48 \mathrm{~d}(46-53 \mathrm{~d})$ following germination, seedlings were transplanted to $20-\mathrm{L}$ pots and placed in outdoor shade houses at the University of Wisconsin Arboretum, Madison, Wisconsin.

\section{Treatments}

Two shade houses $(6.8 \mathrm{~m} \times 6.2 \mathrm{~m} \times 1.4$ to $1.8 \mathrm{~m})$ were covered on all sides with one layer ( $8 \%$ transmittance) of neutral-density shade cloth (Carlin Company, Milwaukee, Wisconsin) and two houses were covered with two layers ( 8 and $27 \%$ transmittance). Measurements of photosynthetic photon flux density measured with quantum sensors (LI-COR, Lincoln, Nebraska) confirmed that our target light levels of 8 and $2 \%$ of open-sky light conditions were achieved. Nine hundred, 20-L plastic pots were filled with a moderately infertile soil (Pence series, sandy loam, $\mathrm{pH}=5.74$ ). The soil was collected from a site $\approx 30 \mathrm{~km}$ east of Eagle River, Wisconsin, in a dry-mesic mixed-forest community (Curtis 1959) with an overstory of $B$. papyrifera, Populus tremuloides, Acer rubrum, and Abies bal- 
samea. The site was classified as Pinus-MaianthemumVaccinium habitat type (Kotar et al. 1988). Seedlings of all the study species except $B$. alleghaniensis are common in this habitat type. B. alleghaniensis is more common on more fertile wet-mesic habitat types in this region of northern Wisconsin (Kotar et al. 1988). Using a front-end loader we scraped away the organic horizon and collected the first $15-20 \mathrm{~cm}$ of the suborganic soil. Soil was raked of rocks and debris before filling pots.

Each of the 900 pots were randomly assigned an individual of each of the five species (180 individuals per species) equally split into two nitrogen treatments (90 for each species). Seedlings were planted after pots were split into equal groups and moved to each of the four shade houses. The low nitrogen treatment consisted of the forest soil amended with all macro- and micronutrients except nitrogen. The high nitrogen treatment had the same supply rate of macro- and micronutrients plus $4.2 \mathrm{mmol} / \mathrm{L} \mathrm{N}$ in equal proportions of $\mathrm{NO}_{3}-\mathrm{N}$ and $\mathrm{NH}_{4}-\mathrm{N}$. Nutrients in the solutions were in proportions suggested by Ingestad (1988). Two hundred millilitres of the solutions were added to potted plants 18 times, at 5-d intervals, during each growing season. This resulted in macronutrient additions in kilograms per hectare per year of: 200 or $0 / \mathrm{N} ; 100 / \mathrm{K}, 50 /$ $\mathrm{P}, 8 / \mathrm{Mg}, 10 / \mathrm{Ca}$, and $20 / \mathrm{S}$.

\section{Measurements}

Leaf photosynthesis was measured in August 1991 with an ADC LCA-2 portable photosynthesis system (Analytical Development Corporation, Hoddesdon, England) that was calibrated against known $\mathrm{CO}_{2}$ standards. Measurements were taken between 1100 and 1300 using the seedlings growth-light environment when conditions outside the shade enclosures were cloudless. Average ( $\pm 1 \mathrm{SE}$ ) photosynthetic photon flux densities during photosynthetic measurements were 45 $( \pm 3)$ and $182( \pm 5) \mu \mathrm{mol} \cdot \mathrm{m}^{-2} \cdot \mathrm{s}^{-1} \mathrm{PPFD}$ in the 2 and $8 \%$ light treatments, respectively, and did not differ significantly among species within a light treatment $(P$ $>0.05$, Tukey-Kramer HSD). One measurement was taken on 3-6 randomly chosen plants for each combination of nitrogen $\times$ species $\times$ house in $8 \%$ light. In $2 \%$ light, 1-4 individuals were measured for each nitrogen $\times$ species $\times$ house combination. Fewer individuals were measured in $2 \%$ light because there were few live individuals and even fewer that had adequate leaf area for measurement. Following photosynthesis measurements leaf punches were taken to determine leaf mass per area (LMA). Photosynthesis on a leaf mass basis was calculated from these LMA values. Photosynthesis was not measured during the 1 st yr because the leaves of most plants were too small.

Three harvests were made during the course of the experiment to determine dry mass of leaves, stems, and roots, and leaf area: (1) immediately prior to transplanting individuals into the experimental treatments in June 1990, 10 extra seedlings of each species were
TABLE 1. Morphology and photosynthesis parameters, with their acronyms and units of meàsure.

\begin{tabular}{lcl}
\hline \hline \multicolumn{1}{c}{ Parameter } & Acronym & \multicolumn{1}{c}{ Units } \\
\hline Leaf mass per area & LMA & g leaf $/ \mathrm{m}^{2}$ leaf \\
Leaf mass ratio & LMR & $\mathrm{g} \mathrm{leaf} / \mathrm{g}$ plant \\
Leaf area ratio & $\mathrm{LAR}$ & $\mathrm{cm}^{2}$ leaf $/ \mathrm{g}$ plant \\
$\begin{array}{l}\text { Stem mass ratio } \\
\text { Root mass ratio }\end{array}$ & $\mathrm{SMR}$ & $\mathrm{g} \mathrm{stem} / \mathrm{g}$ plant \\
$\begin{array}{l}\text { Net photosynthesis } \\
\quad \text { (mass basis) }\end{array}$ & $A_{\text {mass }}$ & $\mathrm{g}$ root $/ \mathrm{g}$ plant \\
$\begin{array}{l}\text { Net photosynthesis } \\
\text { (area basis) }\end{array}$ & $A_{\text {area }}$ & $\mu \mathrm{mol} \mathrm{CO} \cdot \mathrm{CO}_{2} \cdot \mathrm{m}^{-2} \cdot \mathrm{s}^{-1}$ \\
\hline
\end{tabular}

harvested; $(2) \approx 2$ wk before autumnal leaf senescence in year 1 (20-25 September 1990) five or six seedlings were harvested from each combination of species $X$ light $\times$ nitrogen $\times$ house; and (3) late in the second growing season (18-21 August 1991), all remaining seedlings were harvested. Due to differential mortality among treatments the number of seedlings harvested per treatment in 1991 varied $(n=3-34$, average $=16)$ and was lower in $2 \%$ light. Based on these harvest data we calculated leaf, stem, and root mass ratios, leaf area ratio, and leaf mass per area for each plant. Acronyms and units for these and other parameters are summarized in Table 1.

Growth was calculated as a seasonal proportional change in biomass (in grams per gram per year) for light $\times$ species means (see Analysis below for justification of treatment pooling). For year 1 growth = $\ln [$ (mass at end of first growing season) $\times$ (mass of seedlings transplanted to experimental treatments $)^{-1}$ ] and for year 2 growth $=\ln [$ (mass at end of second growing season) $\times$ (mass at end of first growing season $)^{-1}$. Thus, growth rate for the 1 st yr consisted of $\approx 3$ mo, all during the growing season, whereas growth rate for the 2nd yr was for an 11-mo period of which the growing season comprised $\approx 3$ mo. The growth formula we used has been defined as average relative growth rate using the interval approach (Evans 1972). However, because we calculated growth over a long interval and because of the potential for confusing average relative growth rate with the currently more popular expression of instantaneous relative growth rate (Hunt 1978) we will avoid using the term relative growth rate. We also calculated absolute change in biomass (in grams per year) as the difference between final and initial mass with the same harvest data used for proportional change in biomass calculations. Except in the few places in which we compare these measures, we use the term growth to refer to proportional change in biomass.

First-year survival was determined at 1 st-yr harvest (20-25 September 1990) for every individual transplanted into experimental treatments. Second-year survival was determined at $2 \mathrm{nd}-\mathrm{yr}$ harvest time (18-21 August 1991) for every nonharvested individual alive at the end of the first growing season. Herbivory, pri- 
TABLE 2. Mean squares (MS) and $P>F$ values (in parentheses) from least squares ANOVA for plant mass, morphology, and photosynthesis. Data are for all five species for 1990 and for Ostrya, Acer, and Quercus for 1991 . F ratios were calculated for each effect with the residual MS as the error term.

\begin{tabular}{|c|c|c|c|c|c|c|}
\hline & Light & House/light & Species & Nitrogen & $\mathrm{L} \times \mathrm{S}$ & $\mathrm{L} \times \mathrm{N}$ \\
\hline \multicolumn{7}{|l|}{1990} \\
\hline df & 1 & 2 & 4 & 1 & 4 & 1 \\
\hline Mass & $\begin{array}{c}90.372 \\
(<0.0001)\end{array}$ & $\begin{array}{c}0.0565 \\
(0.6860)\end{array}$ & $\begin{array}{l}27.688 \\
(<0.0001)\end{array}$ & $\begin{array}{c}0.2601 \\
(0.3560)\end{array}$ & $\begin{array}{c}2.9175 \\
(<0.0001)\end{array}$ & $\begin{array}{l}0.025 \\
(0.7461)\end{array}$ \\
\hline LMR & $\begin{array}{c}0.1048 \\
(<0.0001)\end{array}$ & $\begin{array}{c}0.0099 \\
(0.2125)\end{array}$ & \multirow{2}{*}{$\begin{array}{c}0.0898 \\
(<0.0001) \\
1881.01 \\
(<0.0001)\end{array}$} & \multirow{2}{*}{$\begin{array}{l}0.0004 \\
(0.8045) \\
98.32 \\
(0.3340)\end{array}$} & $\begin{array}{c}0.1058 \\
(<0.0001)\end{array}$ & $\begin{array}{c}0.0134 \\
(0.1481)\end{array}$ \\
\hline LMA & $\begin{array}{l}6.63 \\
(0.8021)\end{array}$ & $\begin{array}{c}124.99 \\
(0.3051)\end{array}$ & & & $\begin{array}{c}667.50 \\
(0.0001)\end{array}$ & $\begin{array}{l}44.37 \\
(0.516)\end{array}$ \\
\hline \multicolumn{7}{|l|}{1991} \\
\hline $\mathrm{df}$ & 1 & 2 & 2 & 1 & 2 & 1 \\
\hline Mass & $\begin{array}{c}10.671 \\
(<0.0001)\end{array}$ & $\begin{array}{c}0.1659 \\
(0.6880)\end{array}$ & $\begin{array}{c}7.7035 \\
(<0.0001)\end{array}$ & $\begin{array}{l}0.0008 \\
(0.9664)\end{array}$ & $\begin{array}{c}1.3345 \\
(0.0529)\end{array}$ & $\begin{array}{c}0.0001 \\
(0.9880)\end{array}$ \\
\hline LMR & $\begin{array}{c}0.0017 \\
(0.5048)\end{array}$ & $\begin{array}{c}0.0021 \\
(0.5747)\end{array}$ & $\begin{array}{c}0.1135 \\
(<0.0001)\end{array}$ & $\begin{array}{c}0.0046 \\
(0.2689)\end{array}$ & $\begin{array}{c}0.0187 \\
(0.0084)\end{array}$ & $\begin{array}{c}0.0010 \\
(0.6122)\end{array}$ \\
\hline LMA & $\begin{array}{l}58.83 \\
(0.1185)\end{array}$ & $\begin{array}{l}29.87 \\
(0.2284)\end{array}$ & $\begin{array}{l}583.22 \\
(<0.0001)\end{array}$ & $\begin{array}{l}18.68 \\
(0.3771)\end{array}$ & $\begin{array}{l}11.99 \\
(0.6051)\end{array}$ & $\begin{array}{c}0.8101 \\
(0.8538)\end{array}$ \\
\hline$A_{\text {mass }}$ & $\begin{array}{l}23731 \\
\quad(<0.0001)\end{array}$ & $\begin{array}{l}367 \\
(0.1939)\end{array}$ & $\begin{array}{l}2721 \\
\quad(0.0002)\end{array}$ & $\begin{array}{l}498 \\
(0.1360)\end{array}$ & $\begin{array}{l}522 \\
(0.1040)\end{array}$ & $\begin{array}{l}20 \\
(0.7591)\end{array}$ \\
\hline$A_{\text {area }}$ & $\begin{array}{l}59.448 \\
(<0.0001)\end{array}$ & $\begin{array}{c}1.366 \\
(0.0214)\end{array}$ & $\begin{array}{c}0.0504 \\
(0.8449)\end{array}$ & $\begin{array}{c}1.1358 \\
(0.0633)\end{array}$ & $\begin{array}{c}0.6828 \\
(0.1238)\end{array}$ & $\begin{array}{c}0.0334 \\
(0.7406)\end{array}$ \\
\hline
\end{tabular}

marily due to slugs (M. Walters, personal observation), occurred both years in all shade houses. The proportion of leaf area missing was estimated for each individual twice during each year. Leaf area loss was $<12 \%$ for all treatments, and we found no significant differences in plant mass and LAR between data sets consisting of all plants and data sets restricted to plants with $<5 \%$ leaf loss $(P>0.05$ for each species $\times$ light comparison, Tukey-Kramer HSD, data not shown). Therefore, we concluded that the low levels of herbivory witnessed did not influence the results.

\section{Analysis}

The experimental design was completely random with the treatments arranged as a complete factorial of light $(2) \times$ nitrogen $(2) \times$ species $(5) \times$ years $(2)$. For all parameters except growth rate individual pots were the experimental units. Houses were randomly assigned a number ( 1 or 2 ) within a light treatment. Thus houses were considered to be nested within light and the effect of house was tested with two degrees of freedom in the numerator. Prior to analyses the distribution of each response variable was examined for normality (Shapiro-Wilk $W$ test). Natural logarithm (ln) transformations of mass were necessary to normalize variances (Sokal and Rohlf 1981). For all analyses, except survival from year 1 to year 2 , the 2 yr were analyzed separately. We tested for treatment (species $\times$ light $\times$ nitrogen) main effects and interactions on mass, growth, biomass allocation, and photosynthesis with the $F$ statistic from univariate least squares analysis of variance for fixed effects (JMP, SAS Institute, Cary, North Carolina). First-year data sets were balanced, or nearly so, for all response variables. Due to high mortality in some of the treatments 2 nd-yr data sets were imbalanced. Thus some caution should be used in interpreting ANOVA for year 2, since imbalance results in high Type II error rates. In the $2 n d y r$, some of the treatment cells were missing due to the complete mortality of B. alleghaniensis and B. papyrifera in $2 \%$ light. Because of this ANOVA was used on two subsets of the data: (1) all treatment combinations but only for Ostrya, Acer, and Quercus, and (2) for all five species, but with all treatments in $2 \%$ light excluded.

For survival, we tested treatment main effects and interactions with likelihood ratio chi-square tests using a logistic regression model (JMP, SAS Institute, Cary, North Carolina). Likelihood ratio tests were calculated as twice the difference of the log likelihoods between the full model and the model constrained by the effect(s) to be tested (i.e., the model without the effect).

ANOVA and logistic regression results indicated that the vast majority of variation in measured plant traits was due to light, species, and/or light $\times$ species interactions (see Results). Therefore, for subsequent analyses we pooled growth, mass, morphology, and photosynthesis measurements for plants from different nitrogen treatments and houses, and reduced data to light $X$ species means. For a couple of parameters (most notably photosynthesis) nitrogen and house effects 
TABLE 2. Continued.

\begin{tabular}{|c|c|c|c|}
\hline $\mathrm{N} \times \mathrm{S}$ & $\mathrm{L} \times \mathrm{N} \times \mathrm{S}$ & $\begin{array}{l}\text { Residual } \\
\text { MS }\end{array}$ & $\begin{array}{c}\text { Residual } \\
\text { df }\end{array}$ \\
\hline 4 & 4 & & \\
\hline $\begin{array}{c}0.115 \\
(0.1930)\end{array}$ & $\begin{array}{c}0.101 \\
(0.7462)\end{array}$ & 0.299 & 187 \\
\hline $\begin{array}{c}0.0057 \\
(0.4699)\end{array}$ & $\begin{array}{c}0.0052 \\
(0.5162)\end{array}$ & 0.0064 & 186 \\
\hline $\begin{array}{l}51.04 \\
(0.7447)\end{array}$ & $\begin{array}{l}123.21 \\
(0.3222)\end{array}$ & 104.63 & 181 \\
\hline 2 & 2 & & \\
\hline $\begin{array}{c}0.3095 \\
(0.4987)\end{array}$ & $\begin{array}{c}0.5275 \\
(0.3071)\end{array}$ & 0.4421 & 109 \\
\hline $\begin{array}{c}0.0038 \\
(0.3657)\end{array}$ & $\begin{array}{c}0.0020 \\
(0.5812)\end{array}$ & 0.0038 & 109 \\
\hline $\begin{array}{l}17.83 \\
(0.4745)\end{array}$ & $\begin{array}{l}20.28 \\
(0.4287)\end{array}$ & 23.75 & 108 \\
\hline $\begin{array}{l}43 \\
(0.8136)\end{array}$ & $\begin{array}{l}443 \\
(0.1427)\end{array}$ & 208 & 22 \\
\hline $\begin{array}{c}0.2119 \\
(0.5007)\end{array}$ & $\begin{array}{c}0.0653 \\
(0.8044)\end{array}$ & 0.2969 & 22 \\
\hline
\end{tabular}

were significant at $P<0.25$, which is the suggested threshold criterion for pooling variances (Bancroft 1964). For these cases we compared analyses based on light $\times$ species $\times$ nitrogen $\times$ house means with those based on light $\times$ species means. In no cases did we find that reducing data (by pooling data for nitrogen treatments and houses) to light $\times$ species means changed the results and interpretation of our analyses. Light $\times$ species means were compared within light levels and years with Tukey-Kramer HSD tests (JMP, SAS Institute, Cary, North Carolina). This test is conservative if sample sizes for means are different, as was often the case for our 2nd-yr data. Relationships of proportional survival with growth and mass were analyzed with Spearman rank correlation (JMP, SAS Institute, Cary, North Carolina). This technique is insensitive to non-normal data distributions, which are often the case with proportional survival data. For rank correlations with survival we generally focused on mass and growth parameters quantified prior to the survival period, since parameters quantified during a survival period are not independent. Linear regression was used to examine relationships of growth with photosynthesis and morphology.

Morphological parameters (e.g., LAR, LMR, LMA) presented in this report are for plants harvested at the end of the growing season. However, if there was ontogenetic drift in morphology over the growing season and if these dynamics were not parallel among species $\times$ light treatments over the growing season (Walters et al. 1993b), then it is possible that season-end values may not scale with average values over the growing season. We estimated the effect of ontogenetic drift on plant morphology in two ways: (1) by examining relationships between morphological parameters and plant mass or height for individual plants within species, light, and year data sets, and (2) by estimating mean LAR and LMR over the first growing season as the average of transplant germinants and plants harvested at season's end. We found that ontogenetic drift did affect morphology for some parameters and treatments. For instance, larger $2 \mathrm{nd}-\mathrm{yr} B$. papyrifera and B. alleghaniensis seedlings in $8 \%$ light had lower LAR and LMR than smaller plants. However, B. papyrifera and B. alleghaniensis always had higher LMR and LAR than the other three species whether comparisons among species were based on overall means (presented data) or on estimations at a common mass (data not shown). Because ontogenetic drift did not influence interpretation of these and other results we do not report this analysis.

\section{RESULTS \\ Nitrogen}

Nitrogen $(\mathrm{N})$ had no significant effect $(P>0.05)$ on any measured plant trait in year 1 or year 2 (Tables 2 and 3; data not shown for RMR, SMR). We also an-

TABLE 3. Likelihood ratios and $P>\chi^{2}$ (in parentheses) for survival in 1990 and 1991. Likelihood ratios tests are calculated as twice the difference of the log likelihoods between the full model and the model without the tested effect present. The seedling population used for 1990 was the original cohort transplanted into the experimental treatments. The cohort used for 1991 was all plants alive after harvest in Autumn 1990. Number of individuals in survival cohorts were 898 (1990) and 566 (1991).

\begin{tabular}{|c|c|c|c|c|c|c|c|c|c|}
\hline & Light & House/light & Species & Nitrogen & $\mathrm{L} \times \mathrm{S}$ & $\mathrm{L} \times \mathrm{N}$ & $N \times \cdot S$ & $\begin{array}{c}\mathrm{L} \times \\
\mathrm{N} \times \mathrm{S}\end{array}$ & $\begin{array}{c}\text { Full } \\
\text { model } \\
\text { negative } \\
\text { log like- } \\
\text { lihood }\end{array}$ \\
\hline$\overline{\mathrm{df}}$ & 1 & 2 & 4 & 1 & 4 & 1 & 4 & 4 & \\
\hline $\begin{array}{c}\text { Survival } \\
1990\end{array}$ & $\begin{array}{c}0.083 \\
(0.7724)\end{array}$ & $\begin{array}{l}1.385 \\
(0.5003)\end{array}$ & $\begin{array}{c}60.702 \\
(<0.0001)\end{array}$ & $\begin{array}{l}<0.001 \\
(0.9985)\end{array}$ & $\begin{array}{c}35.252 \\
(<0.0001)\end{array}$ & $\begin{array}{l}<0.001 \\
(0.9851)\end{array}$ & $\begin{array}{l}2.077 \\
(0.7216)\end{array}$ & $\begin{array}{l}0.707 \\
(0.9505)\end{array}$ & 109.801 \\
\hline $\begin{array}{c}\text { Survival } \\
1991\end{array}$ & $\begin{array}{l}166.530 \\
(<0.0001)\end{array}$ & $\begin{array}{l}9.183 \\
(0.0101)\end{array}$ & $\begin{array}{l}10.146 \\
(0.0381)\end{array}$ & $\begin{array}{c}<0.001 \\
(0.9957)\end{array}$ & $\begin{array}{c}44.392 \\
(<0.0001)\end{array}$ & $\begin{array}{l}<0.001 \\
(0.9990)\end{array}$ & $\begin{array}{l}1.956 \\
(0.7439)\end{array}$ & $\begin{array}{l}1.974 \\
(0.7406)\end{array}$ & 129.678 \\
\hline
\end{tabular}



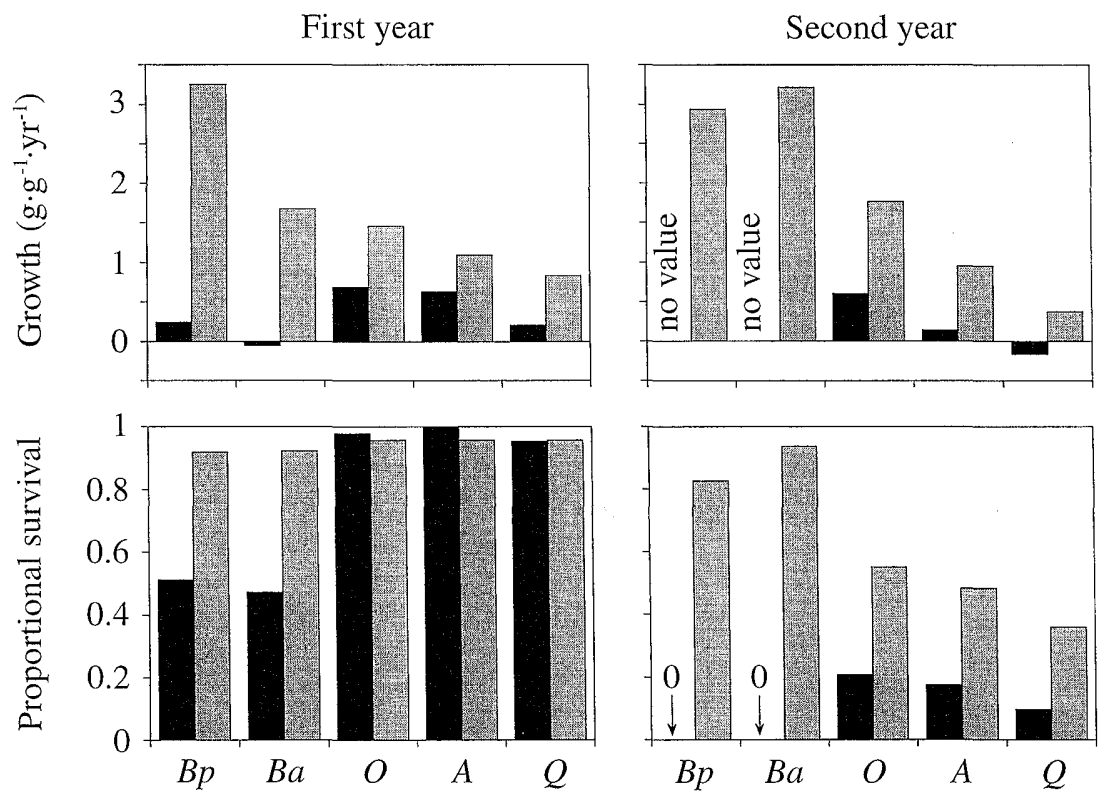

FIG. 1. Growth (proportional change in biomass) and proportional survival for the first and second growing seasons in $2 \%$ (black bars) and $8 \%$ (gray bars) light. Species are ordered (left to right) according to increasing initial seedling mass (Appendix) and seed mass (Walters et al. 1993a) and decreasing relative growth rate in high light (Walters et al. 1993a). Species acronyms are: $B p=$ Betula papyrifera, $B a=$ Betula alleghaniensis, $O=$ Ostrya virginiana, $A=$ Acer saccharum and $Q=Q u e r c u s$ rubra.

alyzed a 2nd-yr data set composed of all five species in $8 \%$ light and found no significant nitrogen effects (data not shown). In contrast, effects of light, species, and species $\times$ light interactions were significant in both years for survival and in year 1 for plant mass, LMA, LMR, LAR, SMR, and RMR. In year 2, light and species effects were large for plant mass, RMR, and SMR, species effects were large for LMR and LMA, and light effects were large for photosynthesis $\left(A_{\text {mass }}\right.$ and $\left.A_{\text {area }}\right)$. Since nitrogen and replicate shade houses were not large sources of variation we pooled data for these effects for the bulk of the following analyses.

\section{Growth, size, and survival}

In $8 \%$ light for both years, growth was highest for small-seeded shade-intolerant $B$. papyrifera and midtolerant $B$. alleghaniensis, lower for shade-tolerant $O s$ trya and Acer, and lowest for large-seeded, disturbance-adapted Quercus (Fig. 1). Relative to $8 \%$ light, species rankings reversed in $2 \%$ light in year 1 . The two most shade-tolerant species, Acer and Ostrya, had higher growth rates than the two Betula species. Quercus had low growth in both light treatments. Despite low growth, but by virtue of a high initial seedling mass Quercus had the greatest mass in year 1 in both light treatments and in year 2 in $2 \%$ light (Table 4 ). However, in $8 \%$ light by the end of year 2 , mass was similar for high-growth, low-seed-mass species ( $B . p a$ pyrifera and $B$. alleghaniensis) and low-growth, highseed-mass species (Quercus). Thus, in $8 \%$ light, it took fourfold differences in growth over $2 \mathrm{yr}$ to overcome a three order of magnitude difference in initial seedling size (Appendix).

In a manner similar to growth, species rankings for survival also switched between 2 and $8 \%$ light, but more so the 2 nd yr (Fig. 1 ). In the 1 st yr $\approx 50 \%$ of the $B$. papyrifera and $B$. alleghaniensis individuals died in $2 \%$ light, whereas few seedlings in other treatments died. In year 2 , of seedlings that were alive the previous autumn all $B$. papyrifera and $B$. alleghaniensis seedlings died, while $20 \%$ of Ostrya and Acer, and $10 \%$ of Quercus seedlings survived (Fig. 1). In contrast, for $8 \%$ light in year $2, \approx 70-80 \%$ of $B$. papyrifera and $B$. alleghaniensis and 35-50\% of Ostrya, Acer, and Quercus seedlings survived. Of the plants that died the 2 nd $\mathrm{yr}$ in $2 \%$ light, about half died during the winter and half during the growing season. In $8 \%$ light most plants died in winter. Probable causes of mortality during the growing season were noted. Several small Betula were uprooted by heavy rain and several Acer and Quercus were killed by rodents, but most plants simply died, presumably of energy starvation. We saw no indication of death from soil-borne fungal pathogens.

Initial seedling mass and 1 st-yr survival rankings were positively related across light environments and in $8 \%$ light (Table 5). In $2 \%$ light, the two Betula species had the lowest initial mass and were the only species to incur high 1st-yr mortality rates. Second-year survival in $8 \%$ light was significantly related to absolute growth rates (in grams per year) (Table 5) and 1st-yr plant mass (Table 5, Fig. 2), but relationships were negative. In contrast, in $2 \%$ light, $8 \%$ light, and 
TABle 4. Mass, morphology, and photosynthesis parameters. See Table 1 for an explanation of parameter acronyms and units. Nitrogen treatments and houses were pooled such that values are the mean of individual plants ( \pm 1 SE) for each year $\times$ light combination. Sample sizes are in the Appendix. Entries in a row followed by the same letter are not significantly different $(P>0.05$, Tukey-Kramer HSD). Mass was transformed by the natural logarithm (ln) prior to calculation of means. Mean mass values presented were backtransformed $\left[e^{\ln (\text { mass })}\right]$ and for SE mass are ln-transformed values. In situ net leaf photosynthesis was measured at $45( \pm 3)$ and $182( \pm 5) \mu \mathrm{mol} \cdot \mathrm{m}^{-2} \cdot \mathrm{s}^{-1}$ PPFD in the 2 and $8 \%$ light treatments, respectively. See Materials and methods for additional details.

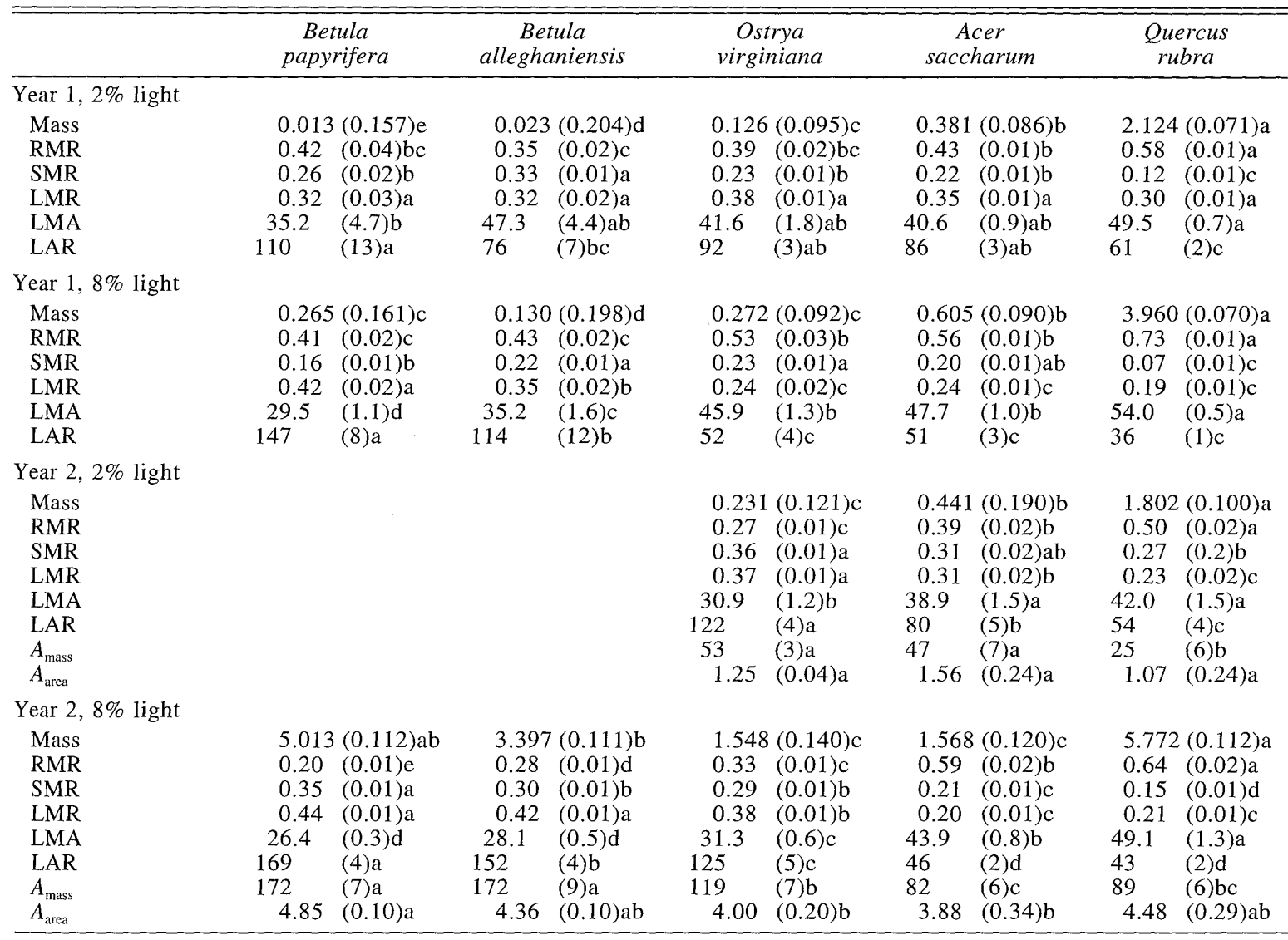

for light treatments combined, 1st-yr proportional growth rate (in grams per gram per year) was positively correlated with 2nd-yr survival (Fig. 2).

\section{Morphology and photosynthesis}

In moderate shade (8\% light) in both years less shade-tolerant Betula species had higher leaf mass ratio (LMR), leaf area ratio (LAR), and lower root mass ratio
(RMR) and leaf mass per area (LMA, i.e., thinner leaves) than shade-tolerant Ostrya and Acer and disturbance-adapted Quercus (Table 4). High LMR was generally associated with low RMR rather than low stem mass ratio. To illustrate, for year 2 in $8 \%$ light Acer was $20 \%$ leaves, $21 \%$ stem, and $59 \%$ roots, whereas $B$. papyrifera was $44 \%$ leaves, $36 \%$ stem, and $20 \%$ roots. Variation in LAR was due to differences in both

TABLE 5. Spearman rank correlations and $P$ values (in parentheses) of 1 st- and 2 nd-yr proportional survival with growth and mass variables quantified prior to the period that survival was assessed. Each datum is a species $\times$ light mean. See Materials and methods for further details on absolute $(\mathrm{g} / \mathrm{yr})$ and proportional growth $\left(\mathrm{g} \mathrm{g}^{-1} \cdot \mathrm{yr}^{-1}\right)$ calculations.

\begin{tabular}{lccc}
\hline \hline$\quad$ Correlated variables & $\begin{array}{c}2 \% \text { light } \\
(n=5)\end{array}$ & $\begin{array}{c}8 \% \text { light } \\
(n=5)\end{array}$ & $\begin{array}{c}2 \text { and } 8 \% \text { light } \\
(n=10)\end{array}$ \\
\hline $\begin{array}{l}\text { First-year survival and: } \quad \\
\quad \text { Initial seedling mass }\end{array}$ & $0.60(0.29)$ & $0.90(0.04)$ & $0.65(0.04)$ \\
Second-year survival and: & & & \\
$\quad$ First-year plant mass & $0.16(0.65)$ & $-1.00(<0.01)$ & $0.25(0.48)$ \\
$\quad$ First-year absolute growth & $0.56(0.32)$ & $-0.90(0.04)$ & $0.40(0.25)$ \\
$\quad$ First-year proportional growth & $0.82(0.09)$ & $0.90(0.04)$ & $0.97(<0.01)$ \\
\hline
\end{tabular}



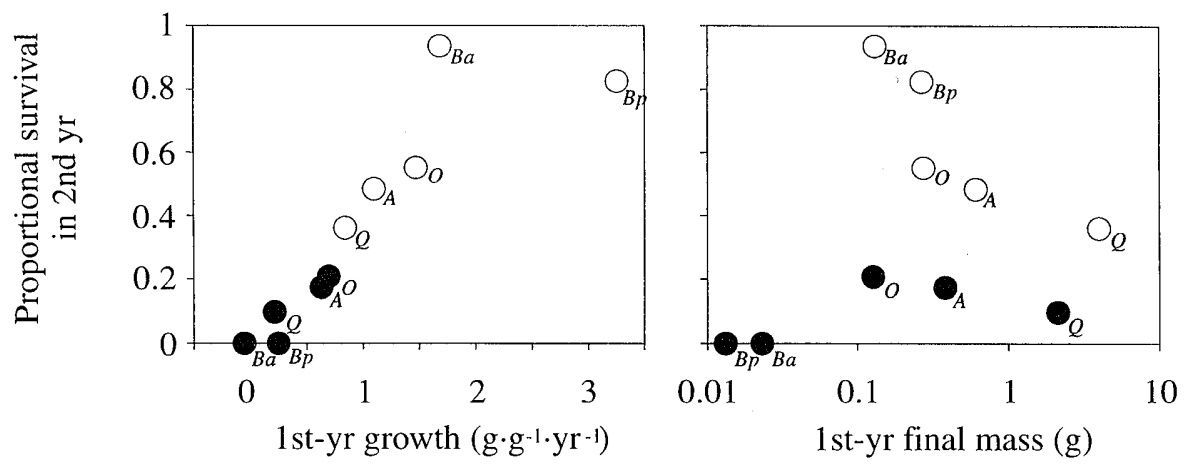

FIG. 2. Proportional survival in the 2 nd-yr vs. 1st-yr growth (proportional change in biomass) and 1 st-yr final mass. Each datum is a species mean in $2 \%(-)$ or $8 \%(\bigcirc)$ light and is labeled with a species acronym: Bp = Betula papyrifera, Ba= Betula alleghaniensis, $O=$ Ostrya virginiana, $A=$ Acer saccharum, and $Q=Q u e r c u s$ rubra. See Table 5 for summary of Spearman rank correlations for these relationships.

LMA and LMR (LAR = LMR/LMA) $($ Table 4). For example, in $8 \%$ light, fourfold higher LAR for $B$. papyrifera than Quercus was the result of $B$. papyrifera having one-half the LMA and twice the LMR of Quercus.

In deep shade ( $2 \%$ light) in year 1 LMR, LMA, and LAR did not differ significantly between Betula species and shade-tolerant Ostrya and Acer (Table 4). In 2 and $8 \%$ light in both years, Quercus tended to be less leafy (low LMR and LAR), had thicker leaves (high LMA), and a higher root mass ratio than any other species.

In 2nd-yr plants, in situ net photosynthesis on an area basis $\left(A_{\text {area }}\right)$ varied by only $\approx 25 \%$ among species in either 2 or $8 \%$ light (Table 4 ), whereas mass-based net photosynthesis $\left(A_{\text {mass }}\right)$ varied by $>100 \%$ in both light environments. In $8 \%$ light, the two Betula species had much greater $A_{\text {mass }}$ than the other three species. In $2 \%$ light Quercus had lower $A_{\text {mass }}$ than Ostrya and Acer.

For 1 st- and 2nd-yr plants in $8 \%$ light and $2 \mathrm{nd}-\mathrm{yr}$ plants in $2 \%$ light, rapid growth rates were associated with high allocation to leaves (i.e., LAR or LMR) (Fig. 3 ). These relationships were not significant in $2 \%$ light in year 1. Relationships of growth with LAR in $8 \%$ light could have been driven, in part, by the fact that these variables share a common component, i.e., final plant mass. We examined this possibility for LMR (LAR and LMR results are similar) by examining the predictions that, if final plant mass drove growth vs. LMR relationships then: (1) final plant mass should be related to both growth and LMR, and (2) relationships should be weak at a common final plant mass. We found no support for plant mass driving growth vs. LMR relationships since (1) in both $8 \%$ light (year 1) and $8 \%$ light (year 2), relationships with final plant mass were insignificant for both growth $\left(R^{2}=0.28, P=\right.$ 0.36 , and $R^{2}<0.01, P=0.98$ respectively) and LMR $\left(R^{2}=0.40, P=0.25\right.$, and $R^{2}<0.01, P=0.96$, respectively), and (2) relationships were strong in $8 \%$ light (year 2) and plant masses were similar among species.
$A_{\text {mass }}$ was related to growth within light environments, but $A_{\text {area }}$ was not (Fig. 4). Across light environments, growth was strongly related to $A_{\text {mass }}$ and more weakly related to $A_{\text {area }}$. We calculated an index of whole-plant net photosynthetic rate as the product LMR $\times A_{\text {mass }}$, which has units of nanomoles of $\mathrm{CO}_{2}$ per gram plant per second (see Walters et al. $1993 b$ for more details). $A_{\text {mass }} \times$ LMR explained slightly more variation in growth than $\operatorname{did} A_{\text {mass }}$ alone (96 vs. $93 \%$ ).

\section{DISCUSSION}

\section{Growth}

Our results demonstrate that growth in very low light is an important component of shade adaptation, both because it is positively correlated with shade tolerances and because of the strong relationship we observed between growth and survival. Studies exploring the relationship between growth rate and ecological attributes have generally found that when grown with abundant resources species adapted to high resource habitats grow faster than species adapted to low resource habitats (Grime and Hunt 1975). Several studies have shown that these growth advantages can be extended to comparisons made under "low" resource conditions (e.g., Loach 1970, Fichtner and Schultze 1992, Walters et al. 1993a). In contrast, we found some species reversals in growth ranking at 2 vs. $8 \%$ light. Ostrya and Acer, whose seedlings are adapted to deeply shaded forest understories, had higher growth rates than the other species in very low light (2\%), whereas seedlings of Betula species, which are adapted to more open early-successional habitats had the highest growth rates at higher light levels (8\% this study, 15-20\% and 75$100 \%$ in Walters et al. 1993a). Why do the current results differ from those found in past studies? One possibility is that few growth comparisons have been made at light levels as low as those found in forest understories. Closed forest understories often receive $<2 \%$ full daylight (Canham et al. 1990, Ellsworth and 

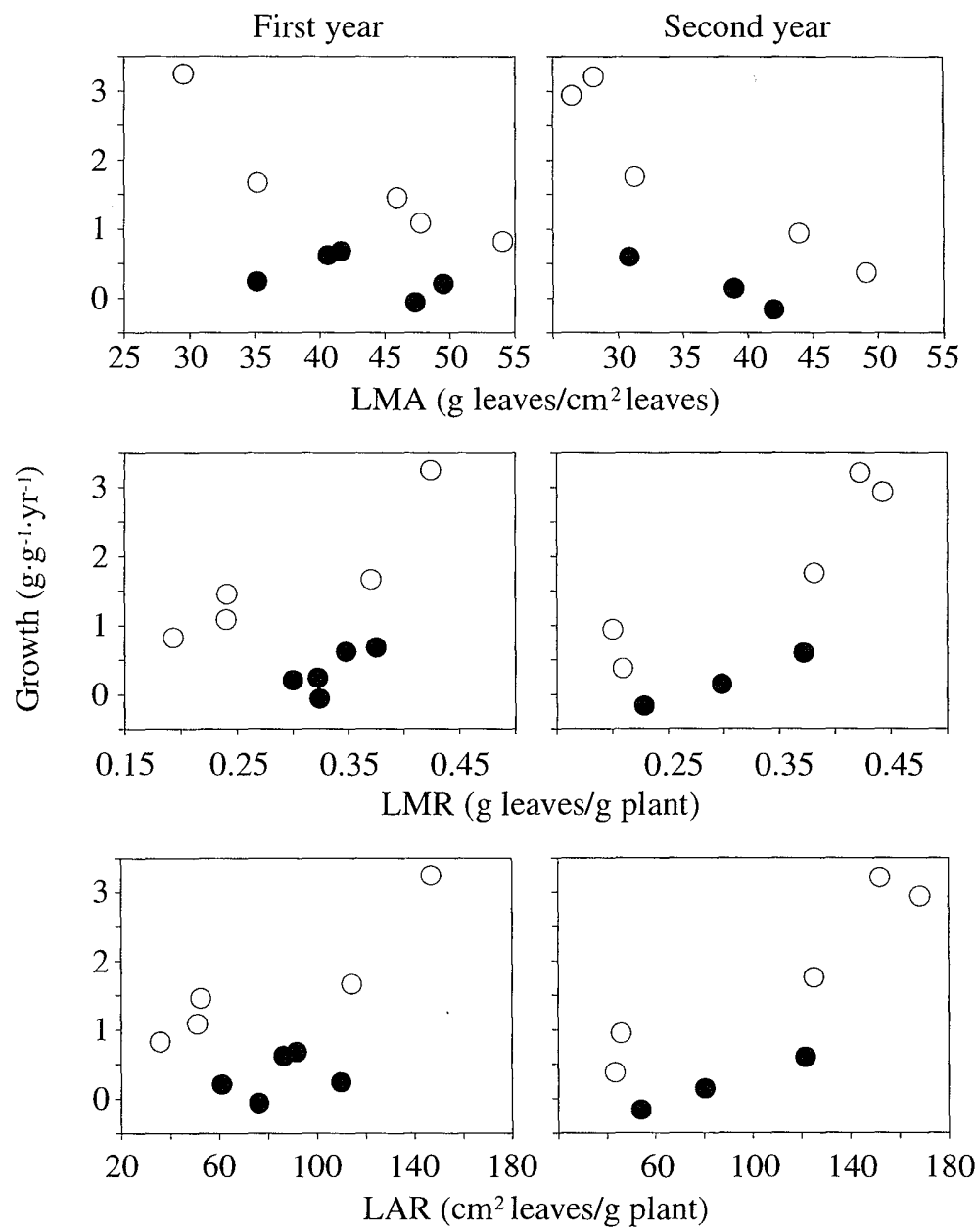

FIG. 3. Growth (proportional change in biomass) vs. leaf mass per area (LMA), leaf mass ratio (LMR), and leaf area ratio (LAR) for 1 st-yr and 2nd-yr plants. Each datum is a species mean in $2 \%(O)$ or $8 \%(O)$ light. Linear regression equations, $R^{2}$ values and levels of significance (*** $P<0.001, * * P<0.01, * P<0.05$ ) are for: 1 st yr, $2 \%$ light; Growth $=\operatorname{LMA}(-0.023)+1.336, R^{2}=0.18 ;$ Growth $=\operatorname{LMR}(8.510)-2.497, R^{2}=0.61 ;$ Growth $=\operatorname{LAR}(0.005)-0.112, R^{2}=$ $0.10 ; 1$ st yr, $8 \%$ light; Growth $=\mathrm{LMA}(-0.086)+5.325, R^{2}=0.82^{*} ;$ Growth $=\operatorname{LMR}(8.625)-0.870, R^{2}=0.80^{*} ;$ Growth $=\operatorname{LAR}(0.018)-0.222, R^{2}=0.83^{*} ; 2$ nd yr, 8\% light; Growth $=\mathrm{LMA}(-0.116)+5.994, R^{2}=0.89^{*} ; \mathrm{Growth}=\mathrm{LMR}(9.818)$ $-1.393, R^{2}=0.86 *$; Growth $=\operatorname{LAR}(0.020)-0.270, R^{2}=0.89^{*}$. Regression statistics for $2 \mathrm{nd}$ yr, $2 \%$ light plants are not shown because of low $n(3)$.

Reich 1992, Walters 1994). Of seven other multiplespecies comparisons of growth rate in high and low light (Loach 1970, McClendon and McMillen 1982, Denslow et al. 1990, Ramos and Grace 1990, Chazdon 1992, Walters et al. 1993a, Kitajima 1994), only three (Pompa and Bongers 1988, Denslow et al. 1990, Kitajima 1994) had light treatments $\leq 2 \%$ of full day light. Of the overall group only Pompa and Bongers (1988) and Denslow et al. (1990) report higher growth rates for shade- than sun-adapted species in low light. Thus, in eight studies (including this one) of growth rate in high vs. low light, three of four cases found higher growth rates for shade- than sun-adapted species when low light treatments were $\leq 2 \%$ of full light, but never when the low light treatment was above that mark.

Although high- and low-light growth rates and survival among four of the species were consistent with their ecological attributes as seedlings, mid-tolerant Quercus had low growth and survival in all light environments. In northern Wisconsin, seedlings of Quercus are most common on dry-mesic forests of low-tomoderate fertility (Curtis 1959, Kotar et al. 1988). Of our five species Quercus had the highest root mass ratio (RMR). High RMR results in low growth for this species in high and low light, because LMR is low. However, high RMR has been shown to be associated with greater competitive ability: (1) to low nutrient availability among grasses (Tilman and Wedin 1991), and (2) following top-kill of all vegetation by fire for Quercus rubra relative to co-occurring woody competitors (Kruger 1992). Thus, high RMR Quercus may be at a competitive advantage in conditions where other factors limit growth and survival more strongly than light.

Interpretation of our growth and survival data re- 

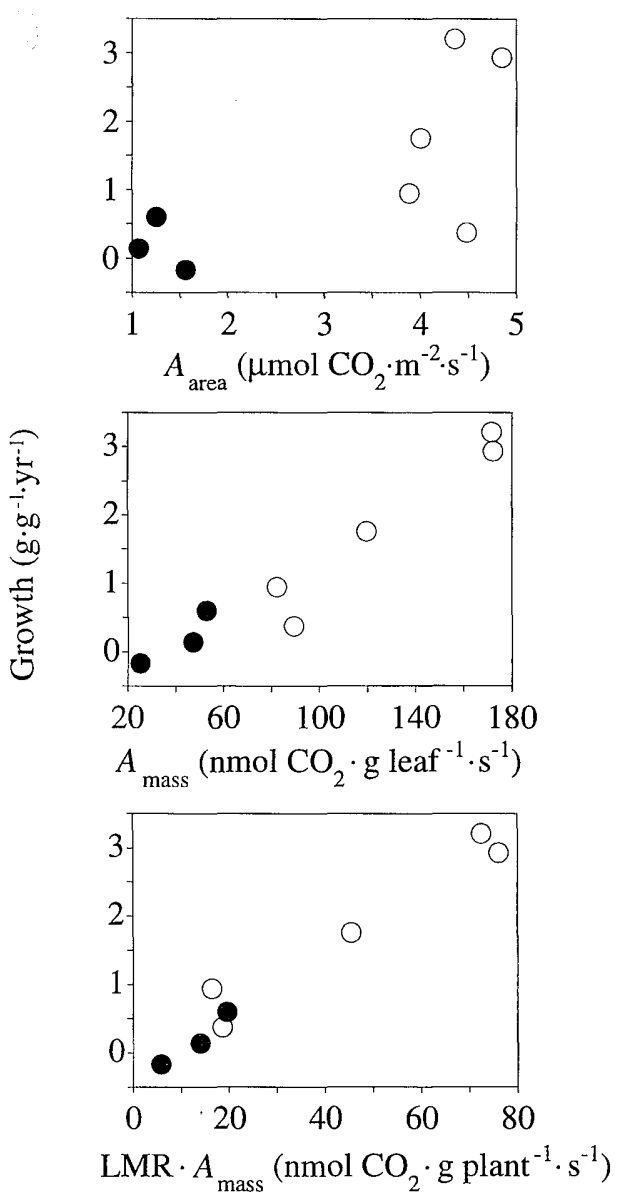

FIG. 4. Growth (proportional change in biomass) vs. in situ net photosynthetic rate on area and mass bases and wholeplant photosynthetic rate (LMR $\times A_{\text {mass }}, \mathrm{nmol} \cdot \mathrm{g}$ plant ${ }^{-1} \cdot \mathrm{s}^{-1}$ ) for 2 nd-yr plants. Each datum is a species mean in $2 \%(\mathbf{O})$ or $8 \%(O)$ light. Linear regression equations, $R^{2}$ values and levels of significance (*** $P<0.001$, **P $P<0.01, * P<$ 0.05 ) are for: $8 \%$ light; Growth $=A_{\text {area }}(1.372)-4.066, R^{2}$ $=0.18 ;$ Growth $=A_{\text {mass }}(0.028)-1.675, R^{2}=0.94 * * ;$ Growth $=\mathrm{LMR} \times A_{\text {mass }}(0.043)-0.093, R^{2}=0.94 * * ; 2$ and $8 \%$ light combined; Growth $=A_{\text {area }}(0.581)-0.628, R^{2}=0.51 *$; Growth $=A_{\text {mass }}(0.023)-0.935, R^{2}=0.93^{* *} ;$ Growth $=\mathrm{LMR}$ $\times A_{\text {mass }}(0.046)-0.331, R^{2}=0.96 * *$. Regression statistics for 2 nd yr, $2 \%$ light plants are not shown because of low $n$ (3).

quires three caveats. First, our shade houses provided a relatively uniform distribution of light with no full sun peaks. This contrasts with the highly dynamic light environments that characterize forest understories. Wayne and Bazzaz (1993) reported that, for birch seedlings receiving the same total amounts of light in shade houses and in artificial gaps, seedlings from shade houses had higher growth rates. This suggests that our seedlings may have had greater growth rates in our 2 and $8 \%$ light treatments than they would have in wellwatered forest understories receiving the same total amounts of light. Furthermore their results suggest that ranking reversals might occur at a higher light level in the field than in our study. Second, light quality in forest understories is shifted to lower red : far red ratios than in either open sky or our shade house conditions. High red : far red ratios have been shown to strongly affect morphology (e.g., greater stem elongation) but not growth in low light (Schmidt and Wulff 1993) and morphology and growth in high light (Ballaré et al. 1991). Therefore, morphological parameters may have differed had we mimicked understory red : far red ratios in our experiment. Third, our calculations of growth are based on populations of plants where mortality has occurred. We observed positive relationships between growth and survival across our experimental treatments in this study. These relationships could also occur within experimental treatments. Thus, growth calculations based on survivors may overestimate true population growth as the survivors would be the individuals with greater growth. Furthermore the magnitude of this overestimation would increase as rates of mortality within a population increased. This implies that comparisons of growth among populations differing in survival may be more conservative (i.e., differences may not be as great) than they might be if growth were measured on both live and dead plants.

Survival for all species was very low in $2 \%$ light, yet even small differences in survival rates in combination with differences in initial population size could potentially explain differences in the abundance and age structure of tree species in forest understories. Given hypothetical annual survival rates for two species of 10 vs. $20 \%$ and original populations of 10000 seedlings, after $4 \mathrm{yr}$ the number of live seedlings would be $1(10 \%)$ and $16(20 \%)$. Walters (1994) found Acer seedling densities as high as 135 seedlings $/ \mathrm{m}^{2}$ (and often $>75 \%$ of total tree seedling density) on understory plots in northern Wisconsin. These data collectively suggest that the success of Acer as a late-successional canopy dominant may be partially due to its ability to maintain large populations of seedlings in the forest understory, which can occur, in part, through higher rates of survival than other species. Qualitatively, our survival data for seedlings are corroborated by data for naturally occurring saplings. Using an indirect method to assess mortality in very low light $(<2 \%)$, Kobe et al. (1995) also predict greater mortality rates in $B$. alleghaniensis than Acer, but compared to our results, mortality rates were very low for both species, even at $\approx 1 \%$ of full light ( 11 vs. $5 \%$ mortality over $5 \mathrm{yr}$, respectively). Large saplings may have markedly lower mortality rates than small seedlings (Turner 1990), even in deep shade, and/or differences in methodology between our study and that of Kobe et al. (1995) may be responsible for the large differences in survival.

\section{Relationships of growth and seedling size with survival}

A large seed and initial seedling size may confer survival in deeply shaded forest understories for a lim- 
ited amount of time, but it may have to be coupled with a high growth rate in order to promote long-term survival (Grime and Jeffery 1965). Large-seeded Quercus is relatively common at low densities as a seedling in low-light understories (Kruger 1992, Walters 1994). However, the results of this study suggest that longterm survival of these seedlings may be low. Smallseeded Betula species incurred higher 1st-yr mortality than other species in both light environments, but mortality was much higher in low light. This pattern could be explained by joint effects of growth rates and initial size on survival if we assume there is a high risk of mortality when seedlings are very small. If this assumption is valid, then Betula species germinants may be at a greater overall risk of mortality in environments where escape from a small size is delayed by low growth rates.

By the 2nd yr survival and growth rate were strongly interdependent, but only when growth rate in the previous year was expressed as a proportional increase in mass over the growing season and not when expressed as an absolute increase in mass over the growing season. However, the interpretation that proportional mass increase is more important than absolute growth rates or plant size as a determinant of survival must include a caveat. Our shade-house treatments mimic the effects of seedling competition for light with a distant overstory. Some forest understories are typified by strong vertical variation in light availability close to the forest floor, such as would occur if tree seedling, herb, or shrub densities were high. In such cases, high seed mass and absolute growth rate may be important for survival, since they may enhance seedling abilities to establish and maintain their foliage in relatively highlight microenvironments (Grime and Jeffery 1965).

Our data suggest that the growth rate-survival relationship may be general since it appears to be continuous regardless of whether the source of variation is species or light. The shape of the growth rate-survival relationship reveals that growth close to 0 results in a high probability of death, with survival increasing strongly and linearly with growth. The linear dependence of survival on growth rate suggests that survival of tree seedlings in forest understories may be contingent on maximizing growth rates and not on merely maintaining a positive growth rate.

\section{Morphology, photosynthesis, and growth}

In general we found that the same traits associated with rapid growth in high light across broad assemblages of species (Lambers and Poorter 1992, Reich et al. 1992) were also associated with rapid growth in high and low light for our study species. High growth rates were correlated with thin leaves (low LMA), high photosynthetic rates per unit mass $\left(A_{\text {mass }}\right)$ and high allocation to leaf mass (LMR) and leaf area (LAR). However, 1 st-yr plants in $2 \%$ light were an exception as relationships with growth rate were weak for LMR,
LMA, and LAR. This may be explained by any one or a combination of: (1) relatively low variation in growth, LMR, and LAR in this treatment; (2) variation in other unmeasured traits affecting growth (e.g., respiration, photosynthesis, and tissue turnover), and (3) seasonal ontogenetic drift in morphological parameters affecting growth that we could not detect with our endpoint measurements of morphology. Acer and Quercus in both years and Ostrya in year 1 had lower LMA and higher LMR and LAR in 2 than $8 \%$ light. In contrast, $B$. papyrifera and $B$. alleghaniensis had much lower LMR and LAR in $2 \%$ than $8 \%$ light. Why? Unlike plants in $8 \%$ light, growth was near zero in $2 \%$ light for the two Betula species. Leaf area and mass changed little in $2 \%$ light, thus leaf allocation and morphology may reflect pretreatment conditions to a greater degree than plants in 8\% light (Appendix). Second, for both Betula species stem mass increased over the growing season while leaf mass increased only slightly (B. papyrifera) or declined ( $B$. alleghaniensis). This resulted in increased stem mass ratio and a static ( $B$. papyrifera) or decreased (alleghaniensis) LMR compared to germinants.

Differences in growth in very low light are small, which suggests that identifying the morphological and physiological mechanisms responsible for variation in growth will require sensitive and intensive techniques. Yet, despite the small magnitude of differences expected in physiology, morphology, and growth, this variation may be ecologically important since, as data in this paper suggest, small differences in growth may have a large effect on survival. Clearly there are several traits that may determine differences in shade tolerance (e.g., variation in germination and early establishment requirements, shoot growth phenology, architecture, leaf and root turnover, pathogen and herbivore protection). Our results demonstrate that variation in growth and survival at the young seedling stage are related to shade tolerance and are likely part of the larger suite of traits that collectively determine shade tolerance.

\section{ACKNOWLEDGMENTS}

The authors wish to thank Bill Klase, Susan Dey, and Trac Nguyen for their expert technical assistance, Eric Kruger and Mark Tjoelker for all kinds of help, Frank Martin for advice on statistics and the University of Wisconsin Arboretum and their staff for putting up with us. The manuscript was improved appreciably by the comments of Bill Pfitsch, Kaoru Kitajima, Mike Tobin, Russell Monson, and four anonymous reviewers. This work was supported by NSF grants BSR8901237 to M.B.Walters and P.B.Reich and DEB-9423065 to P.B.Reich, M.B.Walters, Lee Frelich, and Klaus Puettmann.

\section{LITERATURE CITED}

Baker, F. S. 1949. A revised shade tolerance table. Journal of Forestry 47:179-181.

Ballaré, C. L., R. A. Scopel, and R. A. Sánchez. 1991. On the opportunity costs of the photosynthate invested in stem elongation reactions mediated by phytochrome. Oecologia 86:561-567.

Bancroft, T. A. 1964. Analyses and inferences for incom- 
pletely specified models involving the use of preliminary tests of significance. Biometrics 20:427-442.

Braun, E. L. 1950. Deciduous forests of eastern North America. McGraw-Hill, New York, New York, USA.

Canham, C. D., J. S. Denslow, W. J. Platt, J. R. Runkle, T. A. Spies, and P. S. White. 1990. Light regimes beneath closed canopies and tree-fall gaps in temperate and tropical forests. Canadian Journal of Forest Research 20:620-631.

Chapin, F. S., III, E. D. Schultze, and H. A. Mooney. 1990. The ecology and economics of storage in plants. Annual Review of Ecology and Systematics 21:423-447.

Chazdon, R. L. 1992. Photosynthetic plasticity of two rain forest shrubs across natural gap transects. Oecologia 92: 586-595.

Crow, T. R. 1988. Reproductive mode and mechanisms for self replacement of northern red oak (Quercus rubra)-a review. Forest Science 34:19-40.

Curtis, J. T. 1959. The vegetation of Wisconsin: an ordination of plant communities. University of Wisconsin Press, Madison, Wisconsin, USA.

Denslow, J. S., J. C. Schultze, P. M. Vitousek, and B. R. Strain. 1990. Growth responses of tropical shrubs to treefall gap environments. Ecology 71:165-179.

Ellsworth, D. S., and P. B. Reich. 1992. Leaf mass per area, nitrogen content, and photosynthetic carbon gain in Acer saccharum seedlings in contrasting forest light environments. Functional Ecology 6:423-435.

Evans, G. C. 1972. The quantitative analysis of plant growth. Blackwell Scientific, Oxford, England.

Fichtner, K., and E. D. Schultze. 1992. The effect of nitrogen nutrition on growth and biomass partitioning of annual plants originating from habitats of different nitrogen availability. Oecologia 92:236-241.

Forcier, L. K. 1975. Reproductive strategies and the co-occurrence of climax tree species. Science 189:808-809.

Grime, J. P., and R. Hunt. 1975. Relative growth rate: its range and adaptive significance in a local flora. Journal of Ecology 63:393-422.

Grime, J. P., and D. W. Jeffery. 1965. Seedling establishment in vertical gradients of sunlight. Journal of Ecology 53: $621-642$.

Hunt, R. 1978. Plant growth analysis. Studies in Biology, number 96. Arnold, London, England.

Ingestaad, T. 1988. A fertilization model based on the concepts of nutrient flux density and nutrient productivity. Scandinavian Journal of Forest Research 3:157-173.

Kitajima, K. 1994. Relative importance of photosynthetic traits and allocation patterns as correlates of seedling shade tolerance of 13 tropical trees. Oecologia 98:419-428.

Kobe, R. K., S. W. Pacala, J. A. Silander, and C. D. Canham. 1995. Juvenile tree survivorship as a component of shade tolerance. Ecological Applications 5:517-532.

Korstian, C. F., and T. S. Coile. 1938. Plant competition in forest stands. Duke University School of Forestry Bulletin 3.

Kotar, J., J. A. Kovach, and C. T. Locey. 1988. Field guide to forest habitat types of northern Wisconsin. Department of Forestry, University of Wisconsin-Madison and the Wisconsin Department of Natural Resources, Madison, Wisconsin, USA.

Kruger, E. L. 1992. Survival, growth, root : shoot relations and ecophysiology of northern red oak (Quercus rubra L.) and competing tree regeneration in response to fire and related disturbance in mesic forest openings. Dissertation.
University of Wisconsin-Madison, Madison, Wisconsin, USA.

Lambers, H., and H. Poorter. 1992. Inherent variation in growth rate between higher plants: a search for physiological causes and ecological consequences. Advances in Ecological Research 23:187-261.

Loach, K. 1967. Shade tolerance in tree seedlings. I. Leaf photosynthesis and respiration in plants raised under artificial shade. New Phytologist 66:607-621.

. 1970. Shade tolerance in tree seedlings. II. Growth analysis of tree seedlings raised under artificial shade. New Phytologist 69:273-286.

Lorimer, C. G. 1981. Survival and growth of understory trees in oak forests of the Hudson Highlands, New York. Canadian Journal of Forest Research 11:689-695.

McClendon, J. H., and G. G. McMillen. 1982. The control of leaf morphology and the tolerance of shade by woody plants. Botanical Gazzette 143:79-83.

Pacala, S. W., C. D. Canham, J. A. Silander, and R. K. Kobe. 1994. Sapling growth as a function of resources in a north temperate forest. Canadian Journal of Forestry Research 24:2172-2183.

Pompa, J., and F. Bongers. 1988. The effect of canopy gaps on growth and morphology of seedlings of rainforest species. Oecologia 75:625-632.

Ramos, J., and J. Grace. 1990. The effects of shade on the gas exchange of seedlings of four tropical trees from Mexico. Functional Ecology 4:667-677.

Reich, P. B., M. B. Walters, and D. S. Ellsworth. 1992. Leaf lifespan in relation to leaf plant and stand characteristics among diverse ecosystems. Ecological Monographs 62: 365-392.

Schmidt, J., and R. D. Wulff. 1993. Light spectral quality, phytochrome, and plant competition. Trends in Ecology and Evolution 8:47-50.

Shirley, H. L. 1945. Reproduction of upland conifers in the lake states as affected by root competition and light. American Midland Naturalist 33:537-612.

Sokal, R. R., and J. F. Rohlf. 1981. Biometry. W. H. Freeman, New York, New York, USA.

Spurr, S. H., and B. V. Barnes. 1980. Forest ecology. John Wiley \& Sons, New York, New York, USA.

Tilman, D., and D. Wedin. 1991. Dynamics of nitrogen competition between successional grasses. Ecology 72:10381049.

Turner, I. M. 1990. Tree seedling growth and survival in a Malaysian rain forest. Biotropica 22:146-154.

Walters, M. B. 1994. The physiological ecology of shade tolerance in northern hardwood seedlings. Dissertation. University of Minnesota, St. Paul, Minnesota, USA.

Walters, M. B., E. L. Kruger, and P. B. Reich. 1993a. Growth, biomass distribution and $\mathrm{CO}_{2}$ exchange of northern hardwood seedlings in high and low light: relationships with successional status and shade tolerance. Oecologia 94:716.

Walters, M. B., E. L. Kruger, and P. B. Reich. 1993b. Relative growth rate in relation to physiological and morphological traits for northern hardwood seedlings: species, light environment and ontogenetic considerations. Oecologia 96: 219-231.

Wayne, P. M., and F. A. Bazzaz. 1993. Birch seedling responses to daily time courses of light in experimental forest gaps and shadehouses. Ecology 74:1500-1515.

Zon, R., and H.) S. Graves. 1911. Light in relation to tree growth. U.S. Department of Agriculture Forest Service Bulletin 92. 


\section{APPENDIX}

Leaf area $\left(\mathrm{cm}^{2}\right)$ and organ mass $(\mathrm{g})$ for seedlings just prior to experimental treatments (initial) and end of the 1 st and 2 nd yr in 2 and $8 \%$ light. All parameters were transformed with the natural logarithm prior to determining means. Values presented are back-transformed values. $n$ indicates the number of samples used to generate means.

\begin{tabular}{|c|c|c|c|c|c|}
\hline & $n$ & $\begin{array}{l}\text { Leaf } \\
\text { area }\end{array}$ & $\begin{array}{l}\text { Leaf } \\
\text { mass }\end{array}$ & $\begin{array}{l}\text { Stem } \\
\text { mass }\end{array}$ & $\begin{array}{l}\text { Root } \\
\text { mass }\end{array}$ \\
\hline \multicolumn{6}{|l|}{ Initial } \\
\hline B. papyrifera & 19 & 0.9 & 0.003 & 0.001 & 0.005 \\
\hline B. alleghaniensis & 10 & 2.9 & 0.010 & 0.003 & 0.010 \\
\hline Ostrya & 20 & 14.6 & 0.038 & 0.013 & 0.011 \\
\hline Acer & 10 & 25.0 & 0.081 & 0.060 & 0.058 \\
\hline Quercus & 19 & 116.1 & 0.588 & 0.200 & 0.923 \\
\hline \multicolumn{6}{|l|}{$2 \%$ light, year 1} \\
\hline B. papyrifera & 20 & 1.2 & 0.004 & 0.003 & 0.005 \\
\hline B. alleghaniensis & 21 & 1.7 & 0.007 & 0.007 & 0.008 \\
\hline Ostrya & 20 & 11.3 & 0.046 & 0.028 & 0.049 \\
\hline Acer & 25 & 32.3 & 0.130 & 0.084 & 0.161 \\
\hline Quercus & 20 & 127.2 & 0.629 & 0.247 & 1.223 \\
\hline \multicolumn{6}{|l|}{$8 \%$ light, year 1} \\
\hline B. papyrifera & 20 & 37.6 & 0.110 & 0.042 & 0.106 \\
\hline B. alleghaniensis & 20 & 16.8 & 0.057 & 0.032 & 0.064 \\
\hline Ostrya & 20 & 13.7 & 0.063 & 0.060 & 0.140 \\
\hline Acer & 24 & 29.9 & 0.142 & 0.122 & 0.328 \\
\hline Quercus & 19 & 139.2 & 0.760 & 0.282 & 2.861 \\
\hline \multicolumn{6}{|l|}{$2 \%$ light, year $2 *$} \\
\hline Ostrya & 14 & 27.9 & 0.085 & 0.082 & 0.062 \\
\hline Acer & 11 & 34.6 & 0.134 & 0.132 & 0.168 \\
\hline Quercus & 6 & 96.1 & 0.402 & 0.479 & 0.905 \\
\hline \multicolumn{6}{|l|}{$8 \%$ light, year 2} \\
\hline B. papyrifera & 57 & 799.1 & 2.098 & 1.765 & 1.007 \\
\hline B. alleghaniensis & 60 & 473.4 & 1.336 & 0.943 & 0.894 \\
\hline Ostrya & 38 & 193.1 & 0.600 & 0.458 & 0.501 \\
\hline Acer & 31 & 69.9 & 0.305 & 0.301 & 0.917 \\
\hline Quercus & 25 & 244.7 & 1.190 & 0.837 & 3.677 \\
\hline
\end{tabular}

* Note that B. papyrifera and B. alleghaniensis are omitted from $2 \%$ light, year 2 , since all individuals died. 